\title{
Synthesis of GaN Nanowires with Tantalum Catalyst by Magnetron Sputtering
}

\author{
Xue Chengshan, \\ Qin Lixia, \\ Li Hong, \\ Zhuang Huizhao, \\ Wang Zouping \\ Chen Jinhua, \\ Yang Zhaozhu,
}

Shandong Normal University, Ji'nan 250014, China

\begin{abstract}
Single crystalline wurzite $\mathrm{GaN}$ nanowires were synthesized through ammoniating $\mathrm{Ga}_{2} \mathrm{O}_{3} / \mathrm{Ta}$ films by RF magnetron sputtering. The products were characterized by X-ray diffraction (XRD), scanning electron microscopy (SEM), high-resolution transmission electron microscopy (HRTEM) selected-area electron diffraction (SAED) and photoluminescence (PL). The results show that the nanowires have a hexagonal wurtzite structure with diameters ranging from $20 \mathrm{~nm}$ to $60 \mathrm{~nm}$ and lengths typically up to $10 \mu \mathrm{m}$. The PL spectrum exhibits a strong UV light emission at $363 \mathrm{~nm}$. The growth mechanism of the crystalline GaN nanowires is discussed briefly.
\end{abstract}

Key words: nanostructures; nitrides; sputtering

Gallium nitride $(\mathrm{GaN})$, which has a direct and wide bandgap of $3.4 \mathrm{eV}$ at room temperature, has been considered as an ideal material for the fabrication of blue/green light emitting diodes (LDS), laser diodes (LDS) and high power integrated circuits $^{[1,2]}$. In the past decade, nanomaterials have received extensive research interest for their great prospects in the fabrication of new nanoelectronice and development of new nanotechnologies ${ }^{[3]}$. So far, GaN materials have been synthesized by many different techniques such as carbon nano-tube-confined reaction ${ }^{[4]}$, sublimation method ${ }^{[5]}$, direct reaction of metal $\mathrm{Ga}$ and $\mathrm{NH}_{3}{ }^{[6]}$ and metal-catalyzed growth based on the vapor-liquid-solid (VLS) mechanism ${ }^{[7,8]}$. But, due to the extensive demand for GaN nanoforms in the field of nanotechnology it is still a challenge to fabricate high quality $\mathrm{GaN} 1 \mathrm{D}$ nanoforms. In this paper, $\mathrm{GaN}$ nanowires have been successfully synthesized on Si substrates by RF magnetron sputtering using tantalum as catalyst. This growth method allows a continuous synthesis and produces a large quantity of single-crystal GaN nanowires with relatively high purity and low cost. So, it is to be of interest for commercial-scale production.

\section{Experimental}

In our experiment, GaN nanorods were prepared by self as- sembling of $\mathrm{Ga}_{2} \mathrm{O}_{3}$ films in their reaction with $\mathrm{NH}_{3}$. There were two steps in the whole process. The first step was that the Ta films and $\mathrm{Ga}_{2} \mathrm{O}_{3}$ films were deposited in turn on $\mathrm{Si}$ (111) substrate in a JCK-500A magnetron sputtering system. The targets for depositing Ta films and $\mathrm{Ga}_{2} \mathrm{O}_{3}$ films were Ta with purity of $99.9 \%$ and sintered $\mathrm{Ga}_{2} \mathrm{O}_{3}$ with purity of $99.9 \%$. The conditions of sputtering were as follows: the base pressure before sputtering was about $1.8 \times 10^{-3} \mathrm{~Pa}$. The working gas was pure $\operatorname{argon}(\geq 99.99 \%)$ and the working pressure was 2 $\mathrm{Pa}$. The radio frequency voltage was $900 \mathrm{~V}$ and the sputtering power was $150 \mathrm{~W}$. The sputtering time was about $5 \mathrm{~min}$ for Ta and $90 \mathrm{~min}$ for $\mathrm{Ga}_{2} \mathrm{O}_{3}$.

The second step was that the $\mathrm{Ga}_{2} \mathrm{O}_{3} / \mathrm{Ta}$ films were ammoniated for $10 \mathrm{~min}$ at $950{ }^{\circ} \mathrm{C}$ in the flowing ammonia atmosphere in a horizontal tube furnace. When the tube furnace reached the temperature of $950{ }^{\circ} \mathrm{C}$ steadily, the samples were placed into the constant temperature zone of the furnace. Flowing nitrogen with a flux of $500 \mathrm{~mL} / \mathrm{min}$ was first introduced into the system for $5 \mathrm{~min}$ to expel air. Then ammonia with a flux of $500 \mathrm{~mL} / \mathrm{min}$ flowed into the system for $10 \mathrm{~min}$. Finally, the $\mathrm{NH}_{3}$ was expelled by $\mathrm{N}_{2}$ before the samples were removed from the furnace. It could be found that the color of samples turned to be light yellow after ammoniating.

Received date: June 20, 2008

Biography: Xue Chengshan, Professor, Institute of Semiconductors, Shandong Normal University, Ji'nan 250014, P.R.China, Tel: 0086-531-86182624, E-mail: xuechengshan@sdnu.edu.cn

Copyright (C) 2009, Northwest Institute for Nonferrous Metal Research. Published by Elsevier BV. All rights reserved. 
The crystalline structure information of the as-prepared samples was examined by X-ray diffraction (XRD, Rigaku D/ max-rB Cu $\mathrm{K} \alpha, 40 \mathrm{kV}$ ). Scanning electron microscope (SEM, Hitachi S-570) and high-resolution transmission electron microscope (HRTEM, Philips TECNAI-20) were used to examine the morphology and microstructure of the products. The photoluminescence (PL) spectrum of the samples was analyzed in an FLS920 flourescence spectro-photometer at room temperature.

\section{Results and Discussions}

\subsection{XRD analysis}

Fig. 1 shows the typical XRD pattern of the produced nanowires. Four high peaks are found at $2 \theta=32.26^{\circ}, 34.44^{\circ}, 36.72^{\circ}$ and $48.52^{\circ}$, respectively. All these peaks could be indexed to a hexagonal wurtzite $\mathrm{GaN}$ phase with lattice constants of $a=0.3186 \mathrm{~nm}$ and $c=0.5178 \mathrm{~nm}$, which are the same ones. as the reported value for bulk $\mathrm{GaN}^{[9]}$. No diffraction peaks of $\mathrm{Ga}_{2} \mathrm{O}_{3}$ or other impurities are found in any of our samples, suggesting that the surface of products is predominantly hexagonal wurtzite $\mathrm{GaN}$.

\subsection{SEM analysis}

Fig.2a, b show the typical SEM images of the as-synthesized nanowires ammoniated at $950{ }^{\circ} \mathrm{C}$ at different magnifications. At low magnification, it can be clearly seen from Fig. 2a that the products consist of a large number of high-density nanowires interlaced with each other. Liquid droplets, which are the remarkable sign of the vapor-liquidsolid (VLS) mechanism, are found on the tips of some nanowires, as shown in the inset Fig. 2a. And further observation demonstrates that the nanowires possess a relatively smooth surface and a relatively straight morphology with diameters ranging from $40 \mathrm{~nm}$ to $100 \mathrm{~nm}$ and lengths typically up to $10 \mu \mathrm{m}$, indicating an aspect ratio about 100:1.

Fig.2c is the typical SEM image of $\mathrm{GaN}$ nanorods using $\mathrm{TiO}_{2}$ as the intermediate layer ${ }^{[10]}$. The quality and quantity of the as-synthesized nanowires are better than those of Fig. 2c. In addition, no liquid droplets are found on the tips of the nanorods in Fig. 2c. So, the growth mechanisms are different for the two methods.

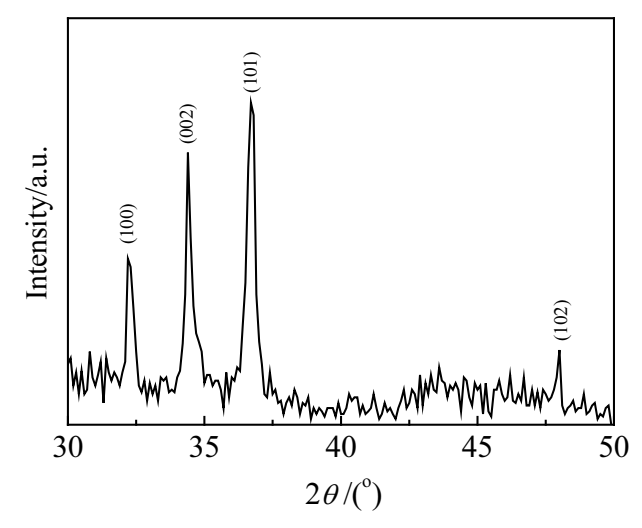

Fig.1 XRD pattern of the synthesized GaN nanowires

\subsection{HRTEM analysis}

The HRTEM images of a single nanowire are given in Fig. 3. Fig. 3a is the image at lower amplification. It reveals that the GaN nanowire with a uniform diameter of about $70 \mathrm{~nm}$ has clean and smooth surface morphology. The inset shows the selected area electron diffraction (SAED) pattern of the single nanowire, where $(0 \overline{1} 11)$, $(1 \overline{1} 01),(10 \overline{1} 0)$ diffraction spots present, which can be indexed to the reflection of hexagonal wurtzite $\mathrm{GaN}$ single crystal. Fig. $3 b$ is the higher-amplification image of the single nanowire. The clear lattice fringes confirm that the nanowire is high quality hexagonal single-crystal GaN. The distance between the two fringes is $0.276 \mathrm{~nm}$, which is corresponding to the plane distance of GaN (100), indicating the growth direction of the nanowire is perpendicular to the fringes of (100) plane.

\subsection{PL analysis}

The measurement of PL spectrum performed at room temperature is shown in Fig.4. A strong UV light emission peak at

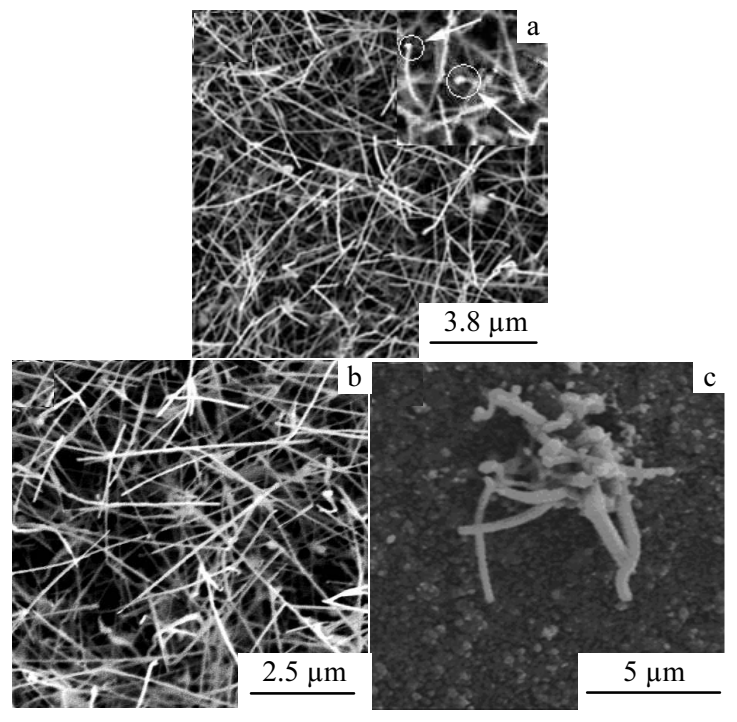

Fig.2 Typical SEM images of GaN nanomaterials at different magnifications: (a) low magnification; (b) higher magnification; and (c) image in Ref[10]

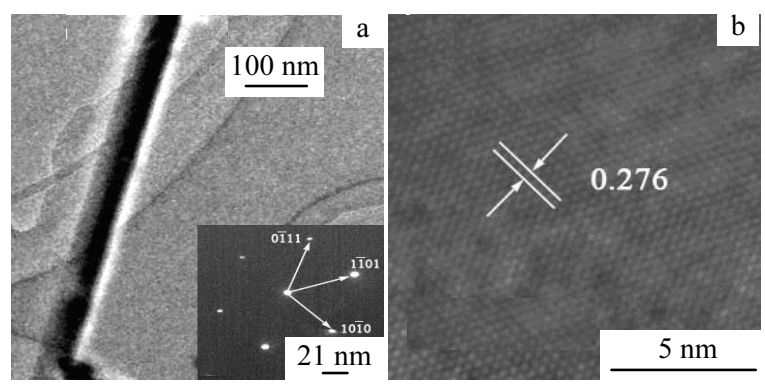

Fig.3 HRTEM images of a single GaN nanowires: (a) lower amplification and (b) higher-amplification 


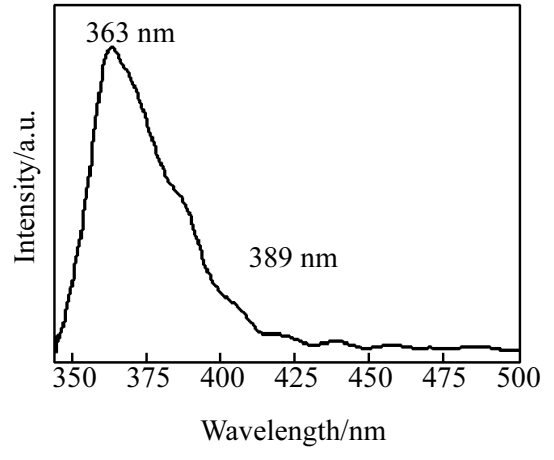

Fig.4 PL spectrum of the synthesized GaN nanowires

$363 \mathrm{~nm}$ and a very weak light emission band centered at 389 $\mathrm{nm}$ can be observed. The UV light emission has tiny blue shift compared with that of bulk $\mathrm{GaN}^{[11]}$. The weak emission band centered at $389 \mathrm{~nm}$ might be due to the excitons bound to the surface or other structure defects ${ }^{[12]}$. However, further work is needed to study the PL mechanism of the GaN nanowires.

\subsection{Discussion about growth process of $\mathrm{GaN}$}

Although the detailed growth mechanism of the GaN nanowires is still not fully understood, we might briefly explain the process based on the above observations. Ta is very important for the fabrication of GaN nanostructure. To text this, we also ammoniated $\mathrm{Ga}_{2} \mathrm{O}_{3}$ /Ta films under the same condition, and no such nanowires were found. As the fluidization temperature of nanosized catalytic metal particles is lower than the melting point of bulk metal ${ }^{[13]}$, the Ta film broke up, and then the liquid Ta nanodroplets which act as energetically favorable sites for absorption of gas-phase reactants are formed on the $\mathrm{Si}$ surface at high temperature. It is well known that $\mathrm{Ga}_{2} \mathrm{O}_{3}$ can decompose to gaseous $\mathrm{Ga}_{2} \mathrm{O}$ or $\mathrm{Ga}$ at the temperature above $800{ }^{\circ} \mathrm{C}^{[14]}$ and $\mathrm{NH}_{3}$ decomposes stepwise to $\mathrm{NH}_{2}, \mathrm{NH}, \mathrm{H}_{2}$ and $\mathrm{N}$ at $850{ }^{\circ} \mathrm{C}$. Then the gaseous $\mathrm{Ga}_{2} \mathrm{O}$, the atomic $\mathrm{Ga}$, the atomic $\mathrm{N}$ and $\mathrm{NH}_{3}$ could be absorbed in above-mentioned sites to form Ta-Ga-N transition alloys. When the concentration of
Ga-N exceeds a saturation point in the liquid phase Ta-Ga-N alloy droplet, $\mathrm{GaN}$ begins to grow from liquid phase and deposits to form nanowires. However, the growth mechanism needs to be further studied.

\section{Conclusions}

1) In summary, $\mathrm{GaN}$ nanowires can be prepared through ammoniating $\mathrm{Ga}_{2} \mathrm{O}_{3} / \mathrm{Ta}$ films on $\mathrm{Si}$ substrate at $950{ }^{\circ} \mathrm{C}$ for 10 $\min$.

2) The nanowires are single-crystal wurtzite $\mathrm{GaN}$ with diameters ranging from $40 \mathrm{~nm}$ to $100 \mathrm{~nm}$ and lengths typically up to $10 \mu \mathrm{m}$.

3) The PL spectrum exhibited a strong emission peak at $363 \mathrm{~nm}$.

\section{References}

1 Yi S N, Jong H N, Kwan H et al. Appl Phys Lett[J], 2007, 90: 101901

2 Nakamura S. Science[J], 1998, 281: 956

3 Morales A M, Lieber C M. Science[J], 1998, 279: 208

4 Han W Q, Fan S S, Li Q Q et al. Science[J], 1997, 277: 12879

5 Goldberger J, He R, Zhang Y. Nature[J], 2003, 422: 599

6 Duan X F, Lieber C M. J Am Chem Soc [J], 2000, 122: 188

7 Zhang J, Zhang L D, Wang X F et al. J Chem Phys[J], 2001, 115: 5714

8 Lyu S C, Cha O H, Suh E K et al. J Chem Phys Lett[J], 2003, 367: 136

9 Perlin P, Jauberthiecarillon C et al. Phys Rev B[J], 1992, 45: 83

10 Sun L, Xue C, Sun C et al. Materials Letters[J], 2007, 61: 5220

11 Monemar B. Phys Rev B[J], 1974, 10: 676

12 Korotkov R Y, Reshchikov M A, Wessels B W. Physica $B[\mathrm{~J}]$, 1999, 273: 80

13 Kim T Y, Lee S H, Mo Y H et al. J Crystal Growth[J], 2003, 257: 97

14 Xu B S, Zhai L Y, Liang J et al. J Crystal Growth[J], 2006, 291: 34

\title{
钽催化磁控溅射法制备 $\mathbf{G a N}$ 纳米线
}

薛成山, 李 红, 庄惠照, 陈金华, 杨兆柱, 秦丽霞, 王 英, 王邹平

(山东师范大学, 山东 济南 250014)

\begin{abstract}
摘 要: 利用磁控溅技术通过氨化 $\mathrm{Ga}_{2} \mathrm{O}_{3} / \mathrm{Ta}$ 薄膜, 合成大量的一维单晶纤锌矿型氮化镓纳米线。用 $\mathrm{X}$ 射线衍射、扫描电子显微镜、 高分辨透射电子显微镜, 选区电子衍射和光致发光谱对制备的氮化镓进行了表征。结果表明: 制备的 $\mathrm{GaN}$ 纳米线是六方纤锌矿结构, 其直径大约 20 60 nm, 其最大长度可达 $10 \mu \mathrm{m}$ 左右。室温下光致发光谱测试发现 $363 \mathrm{~nm}$ 处的较强紫外发光峰。另外, 简单讨论了氮化 镓纳米线的生长机制。
\end{abstract}

关键词: 纳米结构; 氮化物; 溅射

作者简介: 薛成山, 男, 1945 年生, 教授, 山东师范大学半导体所, 山东 济南 250014, 电话: 0531-86182624, E-mail: xuechengshan@sdnu.edu.cn 